\title{
Kuiva-ainepitoisuuden ja säilöntäaineen vaikutus pyöröpaalatun säilörehun laatuun ja maidontuotantoon
}

\author{
Terttu Heikkiläa $^{1)}$, Eeva Saarisalo ${ }^{1,4)}$, Seija Jaakkola ${ }^{2)}$, Anna-Maija Taimisto ${ }^{3)}$ \\ ${ }^{1)}$ MTT Kotieläintuotannon tutkimus, 31600 Jokioinen, etunimi.sukunimi@mtt.fi \\ ${ }^{2)}$ Helsingin yliopisto, Kotieläintieteen laitos, 00014 Helsingin yliopisto, etunimi.sukunimi@helsinki.fi \\ 3) Valio Oy Tutkimus ja tuotekehitys, PL 30,00039 Valio, etunimi.sukunimi@valio.fi \\ 4) Maa- ja metsätalousministeriö, Elintarvike- ja terveysosasto, PL 30, 00023 Valtioneuvosto, etuni- \\ mi.sukunimi@mmm.fi
}

\section{Tiivistelmä}

Rehunteon tehokkuusvaatimus kasvaa tila- ja karjakoon sekä säilörehumäärien suurentuessa. Samalla säilörehun teettäminen urakoitsijalla ja tilojen välinen yhteistyö lisääntyy. Esikuivatun säilörehun teko ja pyöröpaalaus ovat yleistyneet voimakkaasti. Noin 80 \% säilörehusta tehdään jo esikuivattuna (ProAgria 2007). Säilörehua tehdään myös yhä useammin ilman säilöntäainetta. Säilörehun kuiva-ainepitoisuuden noustessa rehun virhekäymisten riski vähenee, mutta hiivojen ja homeiden aiheuttama aerobinen pilaantuminen voi lisääntyä ja aerobinen stabiilisuus huonontua eli rehu lämpenee herkemmin. Sääolosuhteet vaikuttavat esikuivatun säilörehunteon riskeihin, jotka voivat olla erilaiset eri menetelmillä. Alkutuotannon ja maidonjalostuksen laaturiskit rehuntuotantoteknologian kehittyessä tutkimushanke osoitti, että korjuuolosuhteet vaikuttavat enemmän ilman säilöntäainetta tehdyn pyöröpaalisäilörehun ruokinnalliseen arvoon kuin lievästi esikuivatun hapolla säilötyn tarkkuussilputun siilorehun arvoon. Kuivana kesänä tehdyn siilorehun ja yli 50 \% kuiva-ainetta sisältävän paalirehun maidontuotantovaikutus oli yhtä hyvä. Sen sijaan märkänä kesänä paalirehujen syönti ja maidontuotantovaikutus olivat merkitsevästi huonommat kuin siilorehun, vaikka rehut tehtiin hyvän sään aikana (Jaakkola ym. 2006). Tämän tutkimuksen tarkoitus oli selvittää, kuinka säilöntäaine vaikuttaa eri kuiva-ainepitoisuuksissa pyöröpaalatun säilörehun kemialliseen ja mikrobiologiseen laatuun ja jälkipilaantumisalttiuteen sekä maidontuotantoon ja maidon koostumukseen.

Timotei-nurminadan ensimmäisestä sadosta tehtiin pyöröpaalisäilörehua kahdessa eri kuivaainepitoisuudessa (keskimäärin $31 \%$ ja $48 \%$ ) joko ilman säilöntäainetta tai käyttäen AIV $^{\circledR}$ Prohapposäilöntäainetta (muurahaishappoa 42,5 \%, ammoniumformiaattia 30,3 \%, propionihappoa $10 \%$, bentsoehappoa 2,2 \%, vettä $15 \%$ ). Tuoreempi rehu paalattiin niittopäivänä keskimäärin 9 tunnin esikuivauksen jälkeen, kun taas kuivempi rehu paalattiin vasta kolmantena päivänä 56 tunnin esikuivauksen jälkeen, sillä $1,5 \mathrm{~mm}: n$ sade toisena päivänä viivytti kuivumista vuorokaudella. Paalit kiedottiin 6 muovikerroksella (1,2 kg/paali). Säilöntäainetta kului 3,5 l/paali tuoreemmalla ja 3,0 l/paali kuivemmalla rehulla. Maidontuotantokoe tehtiin 16 Ay-lehmällä 4 x 4 latinalaisen neliön mukaan, joka toistettiin neljänä erillisenä neliönä. Säilörehua annettiin vapaasti ja väkirehua (ohra-kaura-melassileikerypsipuriste-kivennäinen) $11 \mathrm{~kg}$ ensikoille ja $13 \mathrm{~kg}$ vanhemmille lehmille.

Säilörehun kuiva-ainepitoisuus ja AIV $^{\circledR}$ Pro-happosäilöntäaineen käyttö vaikuttivat tässä kokeessa melko vähän esikuivatun paalirehun säilönnälliseen ja mikrobiologiseen laatuun sekä rehuarvoihin. Kaikki rehut olivat laadultaan hyviä. Tuoreemmissa rehuissa $\mathrm{pH}$ oli alempi ja happorehussa oli tyypillisesti enemmän sokeria ja vähemmän maitohappoa ja ammoniumtyppeä kuin painorehussa. Kuivempien rehujen laatuerot olivat pieniä. Happo paransi kuitenkin säilörehun aerobista stabiilisuutta. Lämpeneminen alkoi painorehussa noin kahden ja happorehussa neljän vuorokauden kuluttua paalin avaamisesta. Pidempi esikuivatusaika vähensi sekä paino- että happorehun sulavuutta niin, että koko rehuannoksen orgaanisen aineen sulavuus lehmillä huononi keskimäärin 1,2 prosenttiyksikköä. Pidempi esikuivatusaika vähensi painorehun syöntiä, mutta happorehuun se ei vaikuttanut. Maitotuotokseen tai maidon koostumukseen esikuivatusaika tai säilöntäainekäsittely ei vaikuttanut merkitsevästi. Vain maidon urea oli korkeampi kuivemmilla rehuilla. Rehuvalkuaisen hyväksikäytössä maitovalkuaiseksi (keskimäärin 32,5 \%) ei ollut eroa koekäsittelyjen välillä, mutta energian hyväksikäyttö oli kuivemmilla rehuilla parempi. Paalirehujen säilöntätappiot olivat pieniä, noin $2 \%$, mutta 6 muovikerrosta ei täysin estänyt hiiva/homelaikkuja, joita esiintyi suurimmassa osassa paaleista.

Asiasanat: esikuivatus, maidontuotanto, pyöröpaalisäilörehu, säilöntäaine, säilörehun laatu 


\section{Johdanto}

Maidontuotanto perustuu Suomessa runsaaseen säilörehun käyttöön lehmien ruokinnassa sen muodostaessa yli 40 \% lehmien energian saannista. Säilörehun ruokinnallisella ja hygieenisellä laadulla on siten merkittävä vaikutus tuotantotulokseen ja maidon laatuun. Rehunteon tehokkuusvaatimus kasvaa tila- ja karjakoon sekä säilörehumäärien suurentuessa, minkä seurauksena säilörehun teettäminen urakoitsijalla ja tilojen välinen yhteistyö lisääntyy. Esikuivatun säilörehun teko ja pyöröpaalaus ovat yleistyneet voimakkaasti. Noin 80 \% kaikesta säilörehusta tehdään jo esikuivattuna (ProAgria 2007). Säilörehua tehdään myös yhä useammin ilman säilöntäainetta. Säilörehun kuiva-ainepitoisuuden noustessa rehun virhekäymisten riski vähenee, mutta hiivojen ja homeiden aiheuttama aerobinen pilaantuminen voi lisääntyä ja aerobinen stabiilisuus huonontua eli rehu lämpenee herkemmin. Sääolosuhteet vaikuttavat esikuivatun säilörehunteon riskeihin, jotka voivat olla erilaiset eri menetelmillä. Alkutuotannon ja maidonjalostuksen laaturiskit rehuntuotantoteknologian kehittyessä - tutkimushanke osoitti, että korjuuolosuhteet vaikuttavat enemmän ilman säilöntäainetta tehdyn pyöröpaalisäilörehun ruokinnalliseen arvoon kuin lievästi esikuivatun hapolla säilötyn tarkkuussilputun siilorehun arvoon. Kuivana kesänä tehtyjen siilorehujen, joiden kuiva-aine (ka) oli 30-35 \% ja kuivien paalirehujen (ka 53-70 \%) maidontuotantovaikutus oli yhtä hyvä. Sen sijaan märkänä vuonna paalirehujen (ka 39-48 \%) syönti ja maidontuotantovaikutus olivat merkitsevästi huonommat kuin siilorehun (ka 26-28 \%), vaikka rehut tehtiin hyvän sään aikana (Jaakkola ym. 2006). Tämän tutkimuksen tarkoitus oli selvittää, kuinka säilöntäaine vaikuttaa eri kuiva-ainepitoisuuksissa pyöröpaalatun säilörehun kemialliseen ja mikrobiologiseen laatuun ja jälkipilaantumisalttiuteen sekä maidontuotantoon ja maidon koostumukseen.

\section{Aineisto ja menetelmät}

\section{Paalisäilörehujen teko}

Pyöröpaalisäilörehut tehtiin MTT Jokioisten kartanoitten Lintupajun tilalla timotei-nurminadan ensimmäisestä sadosta 16.-18.6. 2005 kahdessa eri kuiva-ainepitoisuudessa (keskimäärin 31 \% ja 48 \%) joko ilman säilöntäainetta tai $\mathrm{AIV}^{\circledR}$ Pro-happosäilöntäaineella (muurahaishappoa 42,5 \%, ammoniumformiaattia 30,3\%, propionihappoa $10 \%$, bentsoehappoa $2,2 \%$, vettä $15 \%$ ), tavoitteena $5 \mathrm{l} / \mathrm{tn}$. Nurmi niitettiin aamupäivällä 8 cm:n sänkeen karholle JF GMS 3200 Topflex-niittomurskaimella. Tuoreempi rehu paalattiin niittopäivän illalla 8-10 tunnin esikuivauksen jälkeen kiinteäkammioisella, silppuavalla ja verkkosidonnalla varustetulla Claas Rollant 250 Roto Cut-paalaimella (vastateriä 14), jossa oli Elho ProFlow 4000-hapotin. Kuivempi rehu paalattiin vasta kolmantena päivänä 55-57 tunnin esikuivauksen jälkeen, sillä 1,5 mm:n sade toisena päivänä viivytti kuivumista vuorokaudella. Paalit kuljetettiin pellon laitaan käärintä- ja varastopaikalle Euro-sovitteisella Quicke Flexigrip-paalipihdillä. Paalit punnittiin paalivaa'alla ja samalla joka neljännestä paalista kairattiin raaka-aine- ja mikrobiologinen näyte ennen kiedontaa ja reiät tukittiin muoviputkella. Paalit käärittiin 6 kerroksella (1,2 kg/paali) valkeaa 750 mm:n Raniwrap-kiristekalvoa Kverneland 7517-kiedontalaitteella. Kiedonnassa käytettiin 50 \%:n limitystä ja 70 \%:n esikiristystä. Paalit varastoitiin pystyasennossa ja ne suojattiin päältä paaliverkolla. Paaleja tehtiin 28 paalia/käsittely eli yhteensä $112 \mathrm{kpl}$. Paalien määrä oli tuoreemmalla rehulla $22 \mathrm{kpl}$ ja kuivemmalla $18 \mathrm{kpl} / \mathrm{ha}$. Paalit punnittiin myös avattaessa ja niistä kairattiin näytteet. Pilaantunut rehu poistettiin ja punnittiin tappioiden määrittämiseksi. Muovit punnittiin kuivauksen jälkeen.

Paalien tuorepainot olivat keskimäärin 747 kg (kuiva-aine 1) ja 592 kg (kuiva-aine 2) ja vastaavasti niissä oli kuiva-ainetta 223 ja 279 kg. Säilöntäainetta kului keskimäärin tuoreemmilla paaleilla 3,5 l/paali ja kuivemmilla 3,0 l/paali ja vastaavasti tonnia kohti ilmaistuna 4,6 ja 5,0 l/tn. Nurmikasvusto sisälsi 64 \% timoteita ja $35 \%$ nurminataa kuiva-aineesta sekä $1 \%$ rikkaruohoja ja kuloa. Timoteista oli tähkällä 22 \% ja nurminadasta röyhyllä 40 \%. Kuiva-ainesato oli 4910 kg ka/ha.

Sää oli rehunteon aikana suhteellisen suotuisa pienestä $1,5 \mathrm{~mm}: n$ sadekuurosta huolimatta. Keskilämpötila vaihteli $15,4-16,9{ }^{\circ} \mathrm{C}$ :een, minimi- ja maksimilämpötilojen ollessa 7,9 ja $23,9{ }^{\circ} \mathrm{C}$ ja maaminimin vaihdellessa $4,9-7,4{ }^{\circ} \mathrm{C}$ :een. Vuorokauden keskimääräinen suhteellinen kosteus oli $67-76 \%$ ja tuulen nopeus 2-3 m/sek. Iltapäivällä klo 15 suhteellinen kosteus oli 35-73 prosenttia ja tuulen nopeus 2-4 metriä sekunnissa. Huhti-toukokuussa satoi 36,1 ja kesäkuussa ennen niittoa 29,4 mm.

\section{Maidontuotantokoe}

Maidontuotantokoe tehtiin 16 Ay-lehmällä, joiden poikimisesta oli kulunut keskimäärin 69 päivää (keskihajonta 24,0). Koemalli oli 4 x 4 latinalainen neliö, joka toistettiin neljänä erillisenä neliönä. 
Yhdessä neliössä kaikki eläimet (4 kpl) olivat ensikoita ja muissa neliöissä kolme, viisi ja 2-4 kertaa poikineita lehmiä. Kaikki lehmät söivät vuorollaan kaikkia koerehuja 3 viikon pituisen koejakson, jonka viimeisen viikon tiedoista laskettiin tulokset.

Säilörehua annettiin vapaasti (20 tuntia) siten, että jätettä jäi päivittäin 5-10 \% annetusta määrästä. Väkirehua vanhemmat lehmät saivat $13 \mathrm{~kg} / \mathrm{pv}$ ja ensikot $11 \mathrm{~kg} / \mathrm{pv}$, joka jaettiin kolmessa erässä. Väkirehu oli tilaseosta: ohra 30,3 \% - kaura 30,0 \% - melassileike 11,0 \% - Öpex-rypsipuriste 26,0 \% kivennäisseos 2,7 \%. Rehuannokset ja jätteet punnittiin päivittäin. Maidot mitattiin Tru-test maitomittarilla yksilökohtaisesti päivittäin. Lehmät punnittiin kunkin jakson alussa ja lopussa kahtena peräkkäisenä päivänä.

Rehunäytteet kerättiin päivittäin rehun punnituksen yhteydessä ja niistä tehtiin taulukoissa mainitut kemialliset analyysit MTT:n Eläinravitsemuksen laboratoriossa. Mikrobit määritettiin säilörehuista Valion laboratoriossa. Rehuannoksen sulavuus määritettiin lehmillä käyttäen merkkiaineena happoon liukenematonta tuhkaa (AIA), joka määritettiin rehunäytteistä sekä jokaisen jakson viiden viimeisen päivän aikana kahdesti päivässä kerätyistä sontanäytteistä 12 lehmältä yksilökohtaisesti.

Maitonäytteet otettiin koejakson viimeisen viikon neljältä lypsykerralta rasva-, proteiini- ja laktoosimäärityksiin ja kahdelta lypsykerralta solumäärityksiin MTT:n Elintarvikkeiden tutkimuksen laboratorioon. Maidon urea määritettiin kahdelta lypsykerralta Eläinravitsemuksen laboratoriossa.

Säilörehujen sulavuus määritettiin in vitro -sellulaasimenetelmällä (D-arvo) ja rehuarvot laskettiin rehutaulukoissa (MTT 2006) esitettyjen laskentaperiaatteiden mukaan. Väkirehuseoksen rehuarvo laskettiin komponenttien osuuksien ja niiden taulukkoarvojen perusteella. Energian saanti ja hyväksikäyttö laskettiin käyttäen lehmillä määritettyä koko rehuannoksen AIA-sulavuutta.

Tuotantokokeen tulokset testattiin varianssianalyysillä (SAS GLM). Mallissa oli seuraavat tekijät: neliö, eläin(neliö), jakso, ruokinta, jakso x ruokinta, neliö x ruokinta. Ruokinnan neliösumma jaettiin edelleen seuraaviin toisistaan riippumattomiin vertailuihin: 1) kuiva-ainepitoisuuden vaikutus, 2) säilöntäaineen vaikutus ja 3) kuiva-ainepitoisuuden ja säilöntäineen välinen yhdysvaikutus.

\section{Tulokset ja tulosten tarkastelu}

\section{Rehujen koostumus, rehuarvot ja laatu}

Säilörehun raaka-aineessa oli niitossa kuiva-ainetta 198 g/kg, sokeria 113 g/kg ka ja D-arvo 71,4 \%. Säilörehujen kemiallisen koostumuksen ja rehuarvojen sekä käymis- ja mikrobiologisen laadun erot olivat suhteellisen pieniä kuiva-ainepitoisuuksien ja säilöntäainekäsittelyjen välillä (Taulukot 1-3).

Taulukko 1. Rehujen kemiallinen koostumus ja rehuarvot

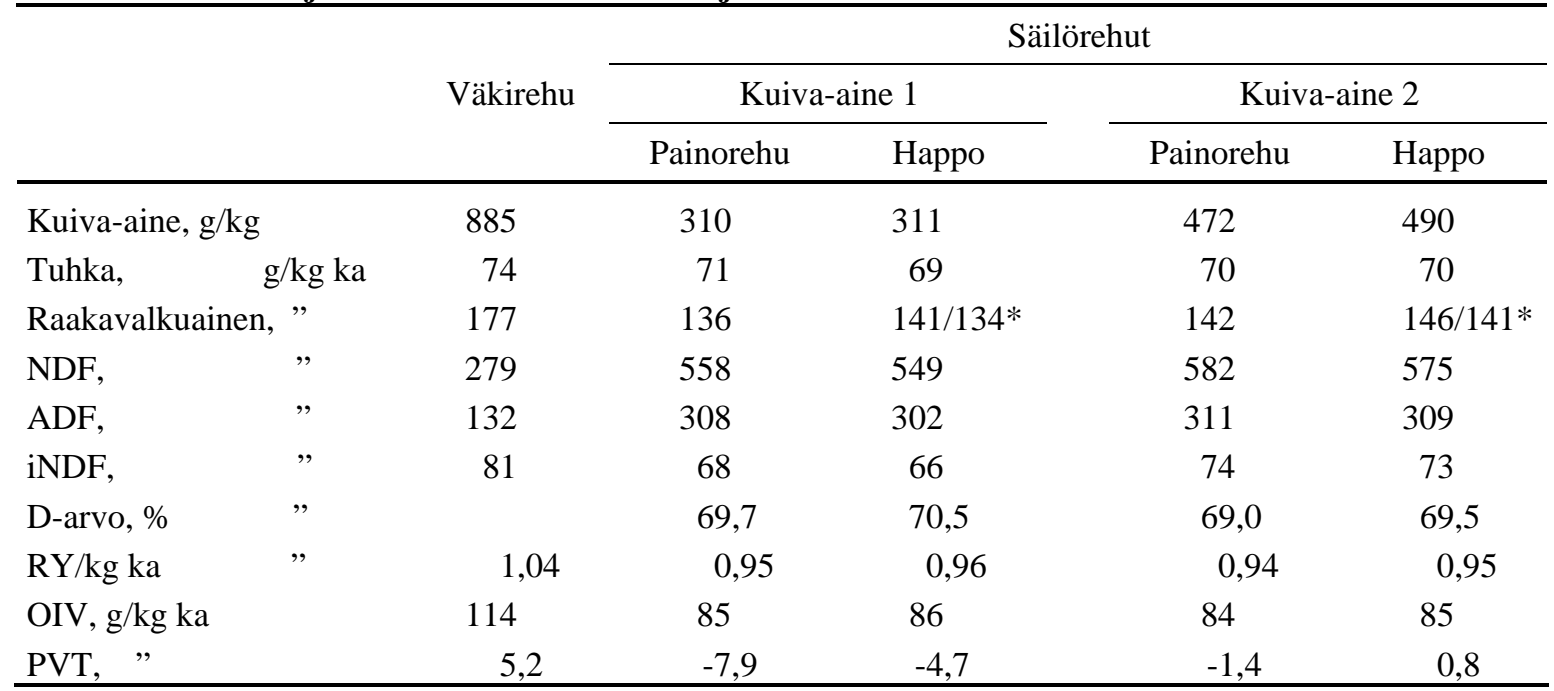

Väkirehussa oli rasvaa 56,1 g/kg ka ja tärkkelystä 33,4 g/kg ka

$\mathrm{NDF}=$ neutraalidetergenttikuitu, $\mathrm{ADF}=$ happodetergenttikuitu, $\mathrm{iNDF}=$ sulamaton NDF $\mathrm{RY}=$ rehuyksikkö, OIV = ohutsuolesta imeytyvä valkuainen, $\mathrm{PVT}=$ pötsin valkuaistase *Happorehuissa raakavalkuainen on ilmoitettu sekä analysoituna pitoisuutena / että säilöntäaineessa lisätyn typen perusteella korjattuna pitoisuutena. 
Kaikki säilörehut olivat käymislaadultaan hyviä (Taulukko 2). Tuoreemmassa happorehussa oli enemmän sokeria ja valkuainen oli hajonnut vähemmän kuin painorehussa. Kuivemmissa rehuissa käyminen oli tyypillisesti vähäisempää kuin tuoreemmissa rehuissa eli $\mathrm{pH}$ ja sokeripitoisuus olivat korkeampia ja maitohappopitoisuus ja ammoniumtypen osuus pienempi kuin tuoreemmissa rehuissa.

Taulukko 2. Pyöröpaalisäilörehujen käymislaatu

\begin{tabular}{|c|c|c|c|c|}
\hline & \multicolumn{2}{|c|}{ Kuiva-aine 1} & \multicolumn{2}{|c|}{ Kuiva-aine 2} \\
\hline & Painorehu & Нарро & Painorehu & Нарро \\
\hline $\mathrm{pH}$ & 4,50 & 4,45 & 5,06 & 5,10 \\
\hline g/kg ka & 50 & 92 & 84 & 94 \\
\hline Maitohappo , & 61 & 36 & 23 & 14 \\
\hline Etikkahappo, & 12 & 10 & 6 & 6 \\
\hline Propionihappo, & 0,6 & $1,9 / 0,1$ & 0,5 & $0,87 / 0$ \\
\hline Voihappo & 0,32 & 0,29 & 0,27 & 0,24 \\
\hline Isovaleriaanahappo ” & 0,07 & 0,08 & 0,08 & 0,09 \\
\hline Etanoli, & 12 & 7 & 7 & 6 \\
\hline Ammonium-N, g/kg N & 63 & 83/33* & 41 & $42 / 8^{*}$ \\
\hline Liukoinen N, " & 774 & $755 / 741^{*}$ & 727 & 689/677* \\
\hline
\end{tabular}

*Happorehuissa ammonium- ja liukoinen typpi ja propionihappo on ilmoitettu sekä analysoituna pitoisuutena / että säilöntäaineessa lisätyn typen ja propionihapon perusteella korjattuna pitoisuutena.

Säilörehujen mikrobiologinen laatu oli hyvä. Pidempi esikuivatusaika lisäsi hieman hiivojen, homeiden ja aerobisten bakteeri-itiöiden määrää säilörehun raaka-aineessa (Taulukko 3). Paalimuovien poistamisen jälkeen kairatuissa varastonäytteissä hiivojen määrä oli hieman pienempi happorehuissa kuin painorehuissa (3,6 vs. 4,4 log pmy/g). Aerobisten bakteeri-itiöiden määrä oli tuoreemmissa rehuissa hiukan pienempi kuin kuivemmissa rehuissa (1,4 vs. 2,4 log pmy/g). Syöttövaiheessa otetuissa näytteissä oli vähän enemmän hiivoja $(4,8$ vs. 4,0$)$ ja homeita $(2,3$ vs. 1,2$)$ kuin paalissa ennen avausta ja näytteiden välinen vaihtelu oli suurempaa. Hiivojen määrä vaihteli syöttönäytteissä 2,8 - 6,7 ja varastonäytteissä 2,5 - 5,5 log pmy/g. Vastaavasti homeiden määrä vaihteli syöttönäytteissä 1 - 5,2 ja varastonäytteissä 1 - 2,9 log pmy/g. Pitkän välivarastoinnin aikana mikrobiologinen laatu voi huonontua.

Taulukko 3. Raaka-aineen ja säilörehun mikrobiologinen laatu

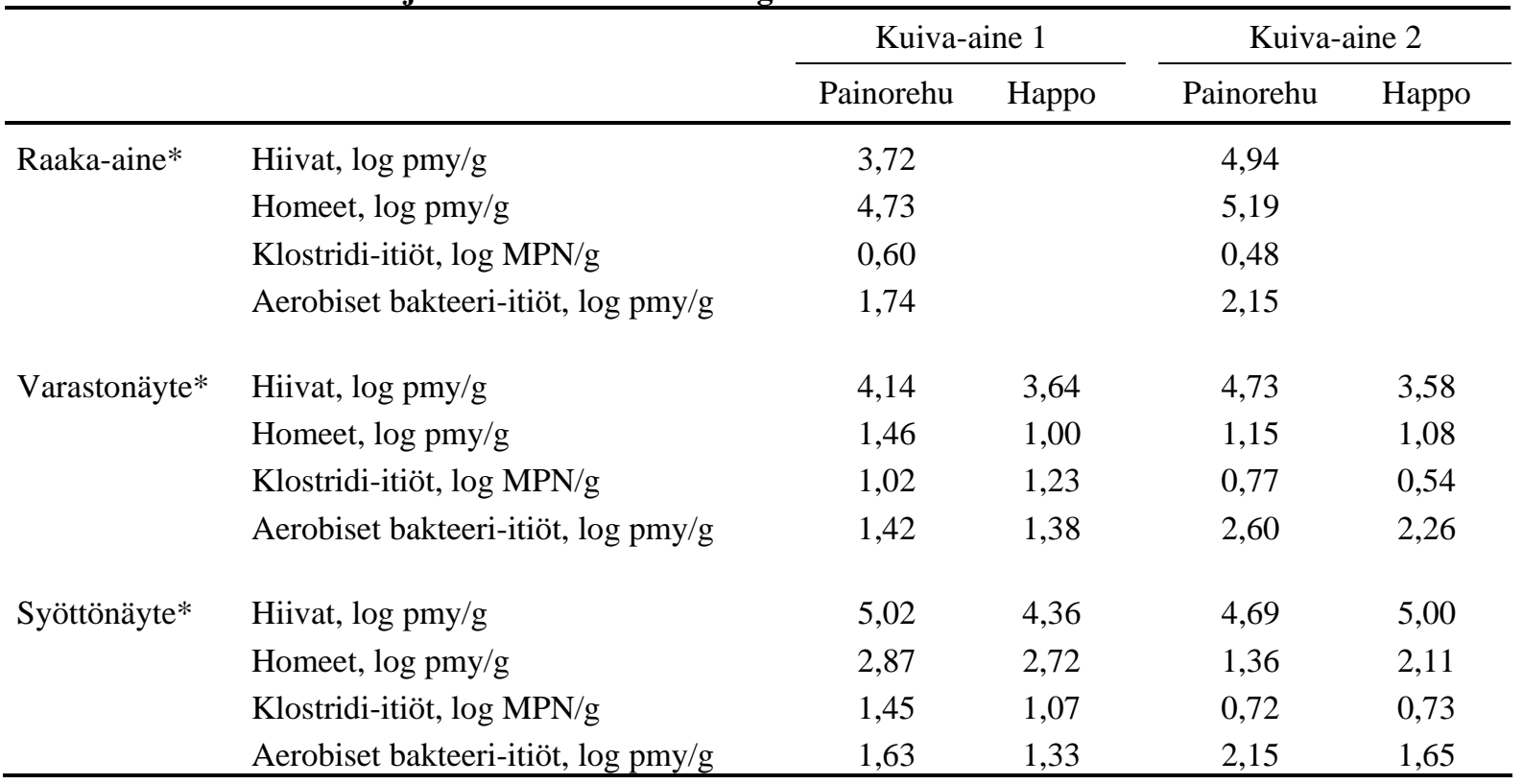

*Raaka-ainenäyte on kairattu paalista ennen käärintää. Säilörehunäytteet on kairattu paalimuovin poistamisen jälkeen (varastonäyte) ja kerätty syöttövaiheessa (syöttönäyte).

pmy = pesäkkeitä muodostava yksikkö, MPN = mikrobien todennäköinen lukumäärä (most probable number) 


\section{Säilöntätappiot}

Pyöröpaalisäilörehujen tuorepainotappio sekä pilaantuneen määrä olivat pieniä. Tuorepainotappio oli keskimäärin vähän suurempi tuoreemmissa kuin kuivemmissa paaleissa ja suurempi painorehu- kuin happopaaleissa: tuoreemmissa 9,4 kg (1,3\%) vs. 7,7 kg (1,0 \%) ja kuivemmissa 6,1 kg (1,0 \%) vs. 4,4 kg (0,7 \%) paalia kohti. Sen sijaan pilaantuneen eli hiivaisen/homeisen/pahanhajuisen rehun määrä oli happorehuissa hieman suurempi kuin painorehuissa, keskimäärin 1,1 \% vs. 0,5 \% tuorepainosta. Vaikka paalien mikrobiologinen laatu oli kairausnäytteiden perusteella hyvä, niin 83 \%:ssa paaleista havaittiin hieman hiivojen/homeiden pilaamaa rehua. Sitä esiintyi pieninä laikkuina paalin pinnassa 5-15 cm:n syvyyteen, enimmillään $40 \mathrm{~cm}: n$ syvyyteen asti. Kuusi muovikerrosta ei riittänyt täysin estämään pilaantumista. Aiemmassa kokeessa neljällä muovikerroksella homeita oli merkitsevästi enemmän kuin kuudella kerroksella ja kahdeksalla hieman vähemmän kuin kuudella (Heikkilä ym. 2002). Kymmenellä muovikerroksella saatiin täysin moitteetonta rehua (Jaakkola ym. 2006). Pilaantunut, homeinen rehu on syytä poistaa, sillä se voi huonontaa syöntiä ja pahimmassa tapauksessa eläin sairastuu. Säilörehussa yleisimmin esiintyvä home Penicillium roqueforti (Sarlin \& Saarisalo 2006) sekä mm. Fusarium-sienet voivat tuottaa homemyrkkyjä.

Sulamaton kuitu (iNDF) ei soveltunut säilöntätappioiden määrittämiseen, sillä säilörehun iNDF oli pienempi kuin raaka-aineen $82 \%$ :ssa tutkituista tapauksista $(\mathrm{n}=28)$.

\section{Aerobinen stabiilisuus}

Happorehujen aerobinen stabiilisuus oli selvästi painorehua parempi. Lämpeneminen alkoi painorehussa vajaan kahden ja happorehussa neljän vuorokauden kuluttua paalin avaamisesta. Tulos on yhdenmukainen aiempien havaintojen kanssa käytettäessä pelkästään muurahaishappoon perustuvaa säilöntäainetta (Heikkilä ym. 1996).

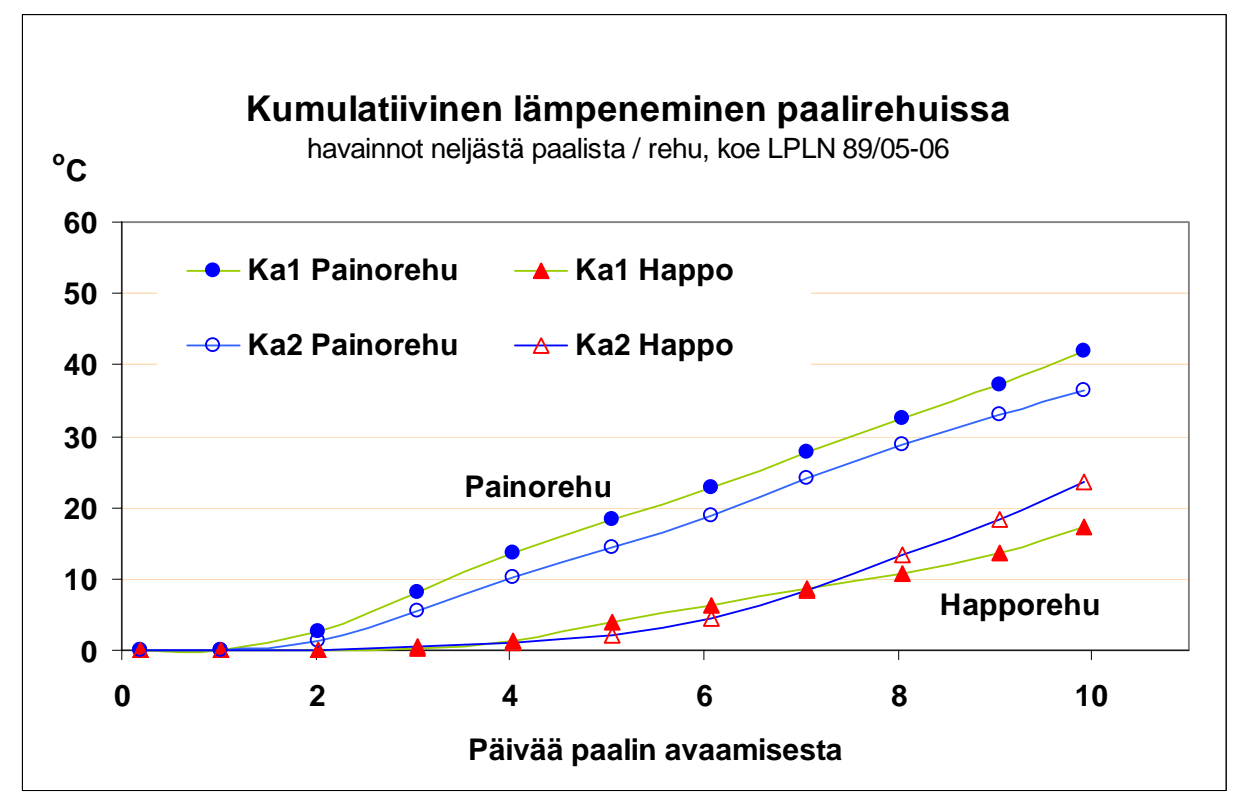

\section{Syönti, maitotuotos ja maidon koostumus, rehun hyväksikäyttö sekä elopaino}

Tuoreemman paalirehun syönti oli keskimäärin runsaampaa kuin kuivemman, mutta koetekijöiden välillä oli yhdysvaikutusta. Lehmät söivät enemmän tuoreempaa kuin kuivempaa ilman säilöntäainetta tehtyä painorehua, mutta hapolla säilöttyjen rehujen syönti kuiva-aineiden välillä oli sama. Väkirehun osuus rehuannoksen kuiva-aineesta oli 47- 48 \% eikä ruokintaryhmien välillä ollut eroa (Taulukko 4).

Maitotuotoksessa, maidon rasva-, valkuais- ja laktoosipitoisuuksissa ja -tuotoksissa ei ollut tilastollisesti merkitseviä eroja paalirehun kuiva-ainepitoisuuksien ja säilöntäainekäsittelyjen välillä. Ainoastaan maidon rasvapitoisuus pieneni suuntaa-antavasti, kun säilönnässä käytettiin happosäilöntäainetta. Maidon ureapitoisuus oli suurempi syötettäessä kuivempaa rehua (22,2 vs. 25,1 mg/dl).

Energian (rehuyksiköiden) kulutus energiakorjattua maitokiloa kohti lehmillä määritetyn sulavuuden mukaan oli suurempi tuoreemmilla rehuilla kuin kuivemmilla ja vastaavasti energian hyväksikäyttö $\left(\mathrm{k}_{12}\right)$ maidontuotantoon parempi kuivemmilla paalirehuilla. Rehuvalkuaisen hyväksikäytössä 
maidontuotantoon (32,1-32.7 \%) ei ollut eroa rehujen välillä. Eläimet lisäsivät painoaan enemmän painorehua kuin happorehua syötettäessä.

Taulukko 4. Paalisäilörehun kuiva-ainepitoisuuden (31 \% ja 48 \%) ja säilöntäaineen vaikutus rehun syöntiin, maitotuotokseen ja maidon koostumukseen, rehun hyväksikäyttöön ja elopainoon

\begin{tabular}{|c|c|c|c|c|c|c|c|c|}
\hline & \multicolumn{2}{|c|}{ Kuiva-aine I } & \multicolumn{2}{|c|}{ Kuiva-aine 2} & \multirow[b]{2}{*}{$\mathrm{SEM}^{1)}$} & \multicolumn{3}{|c|}{$\begin{array}{l}\text { Tilastollinen } \\
\text { merkitsevyys }\end{array}$} \\
\hline & $\begin{array}{l}\text { Paino- } \\
\text { rehu }\end{array}$ & Нарро & $\begin{array}{l}\text { Paino- } \\
\text { rehu }\end{array}$ & Нарро & & $\begin{array}{c}\text { Ka } 1 \\
v s \\
\text { Ka } 2\end{array}$ & $\begin{array}{l}\text { Säil. } \\
\text { aine }\end{array}$ & $\begin{array}{l}\text { Yhd. } \\
\text { vai- } \\
\text { kutus }\end{array}$ \\
\hline \multicolumn{9}{|l|}{ Syönti } \\
\hline Säilörehu, kg ka/pv & 12,7 & 12,4 & 12,1 & 12,4 & 0,14 & $*$ & & $*$ \\
\hline Väkirehu, " " & 11,0 & 11,0 & 11,0 & 11,0 & 0,01 & & & \\
\hline Yhteensä, " & 23,7 & 23,4 & 23,1 & 23,4 & 0,14 & $*$ & & $*$ \\
\hline \multicolumn{9}{|l|}{ Maitotuotos } \\
\hline Maito, $\quad \mathrm{kg} / \mathrm{pv}$ & 35,8 & 36,2 & 35,8 & 36,0 & 0,24 & & & \\
\hline EKM, $\quad "$ & 36,4 & 36,6 & 36,4 & 36,1 & 0,25 & & & \\
\hline Rasva, $\quad \mathrm{g} / \mathrm{pv}$ & 1457 & 1457 & 1454 & 1420 & 15,5 & & & \\
\hline Valkuainen, ” & 1201 & 1200 & 1195 & 1207 & 6,8 & & & \\
\hline Laktoosi, $\quad "$ & 1755 & 1778 & 1762 & 1771 & 12,8 & & & \\
\hline \multicolumn{9}{|l|}{ Maidon pitoisuudet } \\
\hline Rasva, $\quad \mathrm{g} / \mathrm{kg}$ & 40,6 & 40,1 & 40,6 & 39,4 & 0,41 & & 0 & \\
\hline Valkuainen, ” & 33,5 & 33,1 & 33,4 & 33,5 & 0,18 & & & \\
\hline Laktoosi, , " & 49,0 & 49,1 & 49,3 & 49,2 & 0,10 & & & \\
\hline Urea, mg/dl & 21,6 & 22,9 & 24,9 & 25,2 & 0,46 & $* * *$ & & \\
\hline \multicolumn{9}{|c|}{ Energian ja valkuaisen hyväksikäyttö } \\
\hline EKM kg/kg ka & 1,54 & 1,57 & 1,58 & 1,55 & 0,011 & & & $*$ \\
\hline RY2/EKM kg & 0,438 & 0,435 & 0,417 & 0,426 & 0,0039 & $* *$ & & \\
\hline Energian hyv.k. $\left(\mathrm{k}_{12}\right)$ & 0,613 & 0,621 & 0,646 & 0,631 & 0,0060 & $* *$ & & 0 \\
\hline Maitovalk/Rehuvalk & 0,327 & 0,325 & 0,327 & 0,321 & 0,0025 & & & \\
\hline OIV hyväksikäyttö & 0,687 & 0,690 & 0,702 & 0,695 & 0,0049 & o & & \\
\hline Elopaino, kg & 645 & 640 & 643 & 642 & 1,6 & & 0 & \\
\hline Elop. muutos, kg/pv & 0,445 & 0,029 & 0,268 & 0,217 & 0,0999 & & $*$ & 0 \\
\hline
\end{tabular}

Tilastolliset merkitsevyydet: o $\mathrm{P}<0,10$; * $\mathrm{P}<0,05$; ** $\mathrm{P}<0,01$; *** $\mathrm{P}<0,001$, SEM $=$ keskiarvon keskivirhe

${ }^{1)}$ Kuiva-aine 1, Happo-säilörehu: SEM kerrottava luvulla 1,0722 puuttuvien havaintojen vuoksi. Yksi lehmä jouduttiin poistamaan jatkuvien utareongelmien vuoksi ja toisen lehmän yhdet havainnot pötsihäiriön vuoksi. $\mathrm{EKM}=$ energiakorjattu maitotuotos

RY2 = rehuyksiköt on laskettu lehmillä määritetyn koko rehuannoksen AIA -sulavuuden mukaan

$\mathrm{k}_{12}$ =energian hyväksikäyttö maidontuotantoon on laskettu lehmillä määritetyn rehuannoksen AIA -sulavuuden mukaan huomioimatta elopainon muutosta.

Toisin kuin tässä tutkimuksessa aiemmassa kokeessa säilöntäaine (happo ja ymppi) paransi pyöröpaalisäilörehun tuotantovaikutusta: maito- ja valkuaistuotosta sekä valkuaispitoisuutta ja maidon aistinvaraista laatua (Heikkilä ym. 1996). Säilöntäaineella tehtyjen esikuivattujen paalirehujen tai tarkkuussilppurilla tehtyjen siilorehujen välillä ei ole ollut eroa syönnissä eikä maitotuotoksissa, kun rehut ovat olleet hyviä (Heikkilä ym. 1998). Märkänä tehdyn pyöröpaalin laatu voi olla kuitenkin huono (Heikkilä \& Toivonen 2001). Alkutuotannon ja maidonjalostuksen laaturiskejä kartoittavassa tutkimuksessa kuivana vuonna korjuumenetelmien välillä (yli 50 \% kuiva-ainetta sisältävä ilman säilöntäainetta tehty paalirehu vs. tuoreempi hapolla säilötty siilorehu) ei ollut eroa maidontuotannossa, mutta märkänä vuonna paalirehun ongelmana oli syönnin ja sen myötä tuotoksen väheneminen siilorehuun verrattuna (Jaakkola ym. 2006). Korjuumenetelmä ei kuitenkaan vaikuttanut juuston laatuun (Mäki ym. 2006). 


\section{Rehuannoksen sulavuus}

Koko rehuannoksen kuiva-aineen, orgaanisen aineen, happodetergenttikuidun (ADF) ja solunsisällysaineiden sulavuudet lehmillä olivat paremmat syötettäessä tuoreempia kuin kuivempia paalisäilörehuja, mikä johtunee lyhyemmästä esikuivatusajasta. Orgaanisen aineen sulavuus oli 1,2 prosenttiyksikköä pienempi kuivemmilla paalirehuilla. Säilöntäaineen käyttö ei vaikuttanut merkitsevästi sulavuuteen. Aiemmissa kokeissa ruohon orgaanisen aineen in vitro-sellulaasisulavuus laski 1,9 ja 2,4 \%yksikköä ja sokeripitoisuus 1,9 ja 1,7 \%-yksikköä esikuivatusajan pidentyessä 72 tuntiin vuonna 1998 ja 48 tuntiin kuivana vuonna 1999 (Heikkilä ym. 2002).

Taulukko 5. Koko rehuannoksen sulavuus lehmillä

\begin{tabular}{|c|c|c|c|c|c|c|c|c|}
\hline & \multicolumn{2}{|c|}{ Kuiva-aine 1} & \multicolumn{2}{|c|}{ Kuiva-aine 2} & \multirow{2}{*}{$\mathrm{SEM}^{1)}$} & \multicolumn{3}{|c|}{$\begin{array}{l}\text { Tilastollinen } \\
\text { merkitsevyys }\end{array}$} \\
\hline & $\begin{array}{l}\text { Paino- } \\
\text { rehu }\end{array}$ & Нарро & $\begin{array}{l}\text { Paino- } \\
\text { rehu }\end{array}$ & Нарро & & $\begin{array}{c}\text { Ka } 1 \\
\text { vs } \\
\text { Ka } 2\end{array}$ & $\begin{array}{l}\text { Säil. } \\
\text { aine }\end{array}$ & $\begin{array}{l}\text { Yhd. } \\
\text { vai- } \\
\text { kutus }\end{array}$ \\
\hline Orgaaninen aine & 0,721 & 0,726 & 0,713 & 0,711 & 0,0039 & $*$ & & \\
\hline Raakavalkuainen & 0,678 & 0,685 & 0,677 & 0,675 & 0,0052 & & & \\
\hline $\mathrm{NDF}^{2)}$ & 0,627 & 0,631 & 0,625 & 0,626 & 0,0052 & & & \\
\hline $\mathrm{ADF}^{2)}$ & 0,649 & 0,651 & 0,634 & 0,633 & 0,0068 & $*$ & & \\
\hline Solunsisällysaineet & 0,803 & 0,805 & 0,792 & 0,787 & 0,0042 & $* *$ & & \\
\hline Sulava NDF (dNDF) & 0,724 & 0,726 & 0,727 & 0,725 & 0,0045 & & & \\
\hline
\end{tabular}

Tilastolliset merkitsevyydet: * $\mathrm{P}<0,05$; ** $\mathrm{P}<0,01$, SEM $=$ keskiarvon keskivirhe

${ }^{1)}$ Kuiva-aine 1, Happo-säilörehu: SEM kerrottava luvulla 1,0722

${ }^{2)} \mathrm{NDF}=$ neutraalidetergenttikuitu, $\mathrm{ADF}=$ happodetergenttikuitu

\section{Johtopäätökset}

Tämän kokeen hyvissä korjuuolosuhteissa paalirehun kuiva-ainepitoisuudella ja säilöntäainekäsittelyllä oli vain vähän vaikutusta esikuivatun paalirehun säilönnälliseen laatuun. AIV ${ }^{\circledR}$ Pro-säilöntähapon käyttö paransi kuitenkin selvästi pyöröpaalisäilörehun aerobista stabiilisuutta verrattuna ilman säilöntäainetta tehtyyn rehuun. Maitotuotokseen tai maidon koostumukseen paalirehun kuiva-ainepitoisuus tai säilöntäaine ei vaikuttanut merkitsevästi.

\section{Kirjallisuus}

Heikkilä, T., Jaakkola, S., Saarisalo, E., Suokannas, A. \& Helminen, J. 2002. Kuivatusajan, säilöntäaineen ja muovikerrosten vaikutus pyöröpaalisäilörehun laatuun. In: toim. Marketta Rinne. Maataloustieteen Päivät 2002 : Kotieläintiede, 9.-10.1.2002 Viikki, Helsinki. Maaseutukeskusten Liiton julkaisuja 977: p. 66-70.

Heikkilä, T. \& Toivonen, V. 2001. Effect of harvesting methods on silage quality, intake and milk production with or without hay. In: Production and utilization of silage, with emphasis on new techniques : NJF seminar no. 326, Lillehammer 27.-28. September 2001. p. 19-24 .

Heikkilä, T., Toivonen, V., Keskinen, T., Parikka, P. \& Tupasela, T. 1998. Esikuivatun tarkkuussilputun ja pyöröpaalatun säilörehun, säilöntäaineen sekä väkirehumäärän vaikutus maidontuotantoon . In: Kotieläintieteen päivät 1998. Maaseutukeskusten Liiton julkaisuja 924: p. 203-209.

Heikkilä, T., Toivonen, V. \& Tupasela, T. 1996. Säilöntäaineiden vaikutus pyöröpaalauksessa. In: Kotieläintieteen päivät 1996 Kotieläintiede 90 vuotta - juhlaseminaari. Helsinki: Maaseutukeskusten Liitto. p. 231-234.

Jaakkola, S., Saarisalo, E., Heikkilä, T., Nysand, M., Suokannnas, A., Taimisto, A.-M. \& Mäki, M. 2006. Maitoa siilo- vai paalirehulla?. In: Eeva Saarisalo ja Mari Topihulmi (eds.). Rehuntuotantoteknologian kehitys riski maidon laadulle? : Alkutuotannon ja maidonjalostuksen laaturiskit rehuntuotantoteknologian kehittyessä eli Amare-hankkeen loppuseminaari, Jokioinen 26.4.2006. Suomen Nurmiyhdistyksen julkaisu 24: 26-35.

Mäki, M., Pahkala, E., Tupasela, T., Saarisalo, E., Heikkilä, T. \& Jaakkola, S. 2006. Maidon prosessoitavuus ja hygieeninen laatu. Suomen Nurmiyhdistyksen julkaisu 24: 43-50.

ProAgria 2007. Maitotilojen kilpailukyky kehittyy arkisilla asioilla - kannattavuutta nurmirehun laadulla ja viljelytehokkuudella. ProAgria Maito-tulosseminaari. Lehdistötiedote 20.4.2007. 2 p.

Sarlin, T. \& Saarisalo, E. 2006. Säilörehujen homeet ja niiden aiheuttamat riskit. Suomen Nurmiyhdistyksen julkaisu 24: 36-42. 